Acadiensis

Journal of the History of the Atlantic Region

ACADIENSIS

Revue d'histoire de la région Atlantique

\title{
Writing of the Self in New Brunswick and Quebec
}

\section{Andrée Lévesque}

Volume 48, numéro 1, 2019

URI : https://id.erudit.org/iderudit/1062181ar

DOI : https://doi.org/10.1353/aca.2019.0006

Aller au sommaire du numéro

Éditeur(s)

Department of History at the University of New Brunswick

ISSN

0044-5851 (imprimé)

1712-7432 (numérique)

Découvrir la revue

Citer cette note

Lévesque, A. (2019). Writing of the Self in New Brunswick and Quebec. Acadiensis, 48(1). https://doi.org/10.1353/aca.2019.0006 d'utilisation que vous pouvez consulter en ligne.

https://apropos.erudit.org/fr/usagers/politique-dutilisation/ 


\section{Writing of the Self in New Brunswick and Quebec}

\section{THE LAST DECADES HAVE WITNESSED A SURGE OF INTEREST in} autobiographical writings. ${ }^{1}$ Whether one looks at this as the reflection of a narcissistic world, or as a withdrawal from the study of structures and collective entities, there is a proliferation of literary and of scholarly works in literature and in history based on the "writings of the self": journals, letters, memoirs, and autobiographies. In France this is largely due to Philippe Lejeune, who has been collecting unpublished autobiographical writings, analyzing them, and making them available to a wider audience. We are indebted to him for the concept of the "autobiographical pact," where the reader must assume that the author is telling the truth. ${ }^{2}$ The mining of these autobiographical texts has given rise to some outstanding contributions to the cultural and social history of Canada and of Quebec, and especially to the history of women. The two books under review are examples of the best of this type of scholarship: Gail Campbell's "I Wish I kept a Record": Nineteenth-Century New Brunswick Women Diarists and Their World and Patricia Smart's Writing Herself into Being: Quebec Women's Autobiographical Writings from Marie de l'Incarnation to Nelly Arcan. ${ }^{3}$

Both Campbell's work on 19th-century women in New Brunswick and Smart's study of Quebec women from New France to the 2oth century demonstrate how the same kind of sources provide historians with evidence for a range of topics. Just as the census, government reports, and newspaper columns help us reconstruct historical experiences in different periods and at different times, personal writings such as diaries and letters also provide a rich well of information on the experiences and the perceptions of people during

\footnotetext{
Pierre Hébert, with Marilyn Barszczynski, Le Journal intime au Québec. Structure, évolution, Réception (Montréal: Fides, 1988). I would like to thank Bettina Bradbury and Gaby Lévesque for their feedback on this review essay.

2 Philippe Lejeune, Le Pacte autobiographique, collection "Poétique" (Paris: Seuil, 1975).

3 Gail Campbell, "I Wish I kept a Record": Nineteenth-Century New Brunswick Women Diarists and Their World (Toronto: University of Toronto Press, 2017); Patricia Smart, Writing Herself into Being: Quebec Women's Autobiographical Writings from Marie de I'Incarnation to Nelly Arcan (Montréal and Kingston: McGill-Queen's University Press, 2017).
} 
their lifetime. Using women's autobiographical documents, Gail G. Campbell, a specialist in New Brunswick history, and Patricia Smart, a specialist in Quebec literature, investigate women's personal writings for their own purposes. Campbell charts the lives of New Brunswick women from 1825 to 1910, principally from the diaries of 28 women, and none of whom are famous in any generally understood sense of the word. Smart explores the lives of more than 20 Quebec women, from New France to the 21st century, through their published and unpublished diaries and letters. Each work is rooted in a totally different context, from the mysticism characteristic of counter-Reformation Europe and New France to the self-introspection of the last two centuries. Campbell and Smart each ask their own questions. While both examine the construction of the self through personal writings, one enquires about the diarists and their writings while the other explores their place and time. Taken together, they offer rich insights into women's lives in New Brunswick and Quebec.

Embedded in their own place and time, the diaries and letters are subject to their own aims, constraints, and unwritten rules. As Patricia Smart notes, "the amount of self-revelation in [private diaries] is limited by the conventions of their era" (116); and this is all the more true for diaries aimed at publication or those the author supposed were likely to be read by others. There is a fundamental difference between published journals and those destined to remain private. All but one of the diaries studied by Campbell are held in archives, while most of those examined by Smart have been published and often altered in the process. We will never know the content of Henriette Dessaules's unedited diary, started when she was 14 and rewritten about 20 years later. We can only guess at her sister Alice's self-censorship because she had to submit her writings to the nuns who taught her. Never intending it to be read, Joséphine Marchand not only hide her diary but she lied about it to her fiancé - telling him she had burned her notebooks - and Raoul Dandurand was never to see his wife's journal that went on after their marriage. Censorship and self-censorship have to be taken into account even in private diaries, but even moreso when they are destined for a public readership.

Angélique Hay-Des Rivières and Marie-Louise Globensky's diaries were not exactly private. Hay-Des Rivières's chronicles were, at times, written by her son or her daughter in her absence. Her type of diary is the one that most resembles those of the New Brunswick women on whom Campbell has written, with its notes on the garden and the recording on her daily chores. Globensky, 
as Sophie Doucet has recently demonstrated in her doctoral dissertation, wrote for her children and expected her diary to be read after her death. ${ }^{4}$ Michèle Le Normand's diary, not written for public consumption and still in the archives, is much more introspective and open about her emotions and marital trials. Letters can be just as revealing as diaries, and not all are necessarily private. If Élizabeth Bégon's letters to her son-in-law were not written for publication, other correspondence was certainly meant to be shared and read out loud.

What sets unpublished diaries and letters apart is that they are rarely written for a wider audience. As historical records, they are precious because they are often written "à chaud" - or on the spot - without the knowledge of what would come after a certain event or what the consequences may be. Diarists might at times reminisce about past events, looking at their lives in retrospect, but they seldom write for a broad public. Autobiographies and memoirs, on the other hand, put even more distance between their authors and their times. Written after the fact, they are malleable to the image the author wants to project but, as in the case of Gabrielle Roy's Enchantment and Sorrow, the auto-biographer can still respect Lejeune's "pact" (238). Finally, the diaries found by Campbell were largely written in the present. In contrast, a number of Smart's subjects wrote a posteriori and took time to revise their text or had someone else undertake edits for publication. This could, at times, influence the tone and content of these altered texts.

\section{Nineteenth-century New Brunswick women}

Suzanne Morton wrote in Atlantis in 2000 that scholarship on women's history reflects the difficulty in "reconciling the study of gender and the regional framework." This is not the case in Campbell's book, where the diarists are firmly anchored to their Maritime region whether in their personal journals or in the author's analysis. Hers is not the first study of Atlantic women's personal writing. During the 1980 os Margaret Conrad published two books of Atlantic women's autobiographical writings since 1750, which had a particular focus on Nova Scotia women. ${ }^{6}$ The originality of Campbell's book lies in its

Sophie Doucet, "Toujours je sens mon âme se balancer entre les joies et les peines," Le paysage émotionnel de MarieLouise Globensky (1849-1919) vu à travers ses écrits personnels (PhD diss., McCill University, 2018).

5 Suzanne Morton, "Gender, Place, and Region: Thoughts on the State of Women in Atlantic Canadian History," Atlantis XXV, no. 1 (Fall 2000): 119-28.

6 Margaret Conrad, Toni Laidlaw, and Donna Smith, eds., There's No Place Like Home: Diaries and Letters of Nova Scotia Women, 1871-1939 (Halifax: Formac, 1988); Margaret Conrad, Recording Angels: The Private Chronicles of Women from the Maritime Provinces of Canada, 1750-1850 (Ottawa: Canadian Research Institute for the Advancement of Women 1982). On the subject of women's autobiographical writings, one should also mention Kathryn Carter, ed., Small Details of Life: Twenty Diaries by Women in Canada, 1830-1996 (Toronto: University of Toronto Press, 2004). 
concentration on 19th century New Brunswick and in the use she makes of autobiographical writings. Her introductory chapter on "Reading NineteenthCentury Diaries" is particularly useful to anyone consulting autobiographical sources. She distinguishes between different kinds of diaries and their purposes: some that are shared, some that serve as secret confidante, and others that are travelogues. She also notes their material composition, from bits of paper to bound notebooks, and defines their style - narrative or dialogues. All are "an individual version of a life ... as individual as their author" (48).

Campbell's diarists form a fairly homogenous group: they all descended from Loyalists and Protestant British immigrant families. Although Acadians formed between 15 per cent and 28 per cent of the population between 1871 and 1911, Campbell admits to finding no diaries written by Acadian women or by Catholic women - the latter of whom formed 34 per cent of the New Brunswick population in 1861 (325). Most Roman Catholics were Acadians or Irish settlers, two groups situated at the lower echelons of the socio-economic ladder. This may in part explain why she did not find their journals and letters: child labour was often essential to the family economy, resulting in a lower literacy rate than among their Protestant British neighbours. Moreover, the establishment of non-denominational public schools in the province in 1871 meant that Irish and Acadian children were not encouraged to attend school.

Personal diaries can be used to provide additional material on information found elsewhere, to illustrate certain events, or as sources in themselves. On the other hand, they need to be contextualized. The 28 women's journals Campbell explores do not tell the full story of the women who were spread over 11 counties. To complement her research, the author relies on the government census and other statistics to present a demographic background for her diarists. The book then proceeds thematically through the stages in life - from courtship to family formation to "the midst of life" (284-302).

The question of representativity is foremost amongst historians' concerns when considering personal writings. The important third chapter entitled "The Life Course in Demographic Context," could be situated more closely, within the areas from whence the diarists came. I would have welcomed more comparison between the women who left their own testimonies and the majority of New Brunswick women at the time. For instance, how do they compare with their cohorts with respect to their fertility, mortality rates, and so on? Apart from dealing with their authors' personal lives, the diaries also reveal their contribution to the family economy - especially in the farming/ 
lumbering families. This, too, would benefit from comparison with the general population. Even the most laconic diary possesses its own eloquence, as when Janet Hendry MacDonald jotted down her daily chores, "I am spinning flax" (213) without additional comment. Cryptic entries such as this one gives us an idea of the variety, the importance, and at times the tedium of women's work in and around the home.

Women's autobiographical papers can also be used for the now-popular history of emotions. ${ }^{7}$ On the whole, one gets a picture of harmonious relationships where cheerfulness is broken only by illnesses or death. The happy disposition of most diarists raises questions about the expression of feelings: could it be that even in the secrecy of one's journal, a woman had to refrain from complaining?

Diaries and letters inform us of almost everything that pertains to the home and its surroundings. They are a rich source for the study of sociability and leisure: parties, card games, and crokinole are recurrent activities, while courtships, friendships, flirtations, and rivalries also have their place in women's diaries and letters. Religion is omnipresent. Women pray, go to church, sing in the choir, celebrate baptisms, and raise funds for their congregations.

The autobiographical evidence in Campbell's book broadens the scholarship on Maritime history, especially that based on economic development and relationships with the metropolis, by including women's contributions to their families and their community's economy. Personal writings enhance political history by showing the role of women in political parties, even before they had the right to vote, and in the reform and temperance movements that were closely tied to politics. Campbell insists, and rightly so, on the continuum between the private and the public. In 1989 she published "Disenfranchised But Not Quiescent: Women Petitioners in New Brunswick in the Mid-Nineteenth Century," some of which is incorporated in her section on women in the public sphere. ${ }^{8}$ She moves us beyond the dichotomy that was popular in the first accounts of women's lives generally during the 19th century and those of New Brunswick women, underscoring that, never far from the sea, they reached beyond their immediate borders. In a staple-producing and export-driven

William M. Reddy, The Navigation of Feeling: A Framework for the History of Emotions (Cambridge: Cambridge University Press, 2006); Jean Corbin, Jean-Jacques Courtine, and Coerges Vigarello, eds., Histoire des émotions, 3 vols. (Paris: Seuil, 2016-1017); Rob Boddice, The History of Emotions (Manchester: Manchester University Press, 2018).

8 Gail Campbell, "Disenfranchised But Not Quiescent: Women Petitioners in New Brunswick in the Mid-Nineteenth Century," Acadiensis XVIII, no. 1 (Autumn 1989): 22-54. 
economy, women felt the impact of imperial policies and the opening of a North American job market. Campbell stresses that they were as well read as their British and American counterparts. Contrary to the tired stereotype, women were very much present in what is known as the public sphere. They were "the heart of the family, at the heart of the community" (308). Single women, some widows, and a few wives also held remunerated work outside the home.

Throughout, I found myself wondering if the situation was the same for Acadian and other Catholic women. Referring to Philipe Lejeune, Campbell writes: "In the early nineteenth-century young women were encouraged to use their diaries as an expression of faith and a means of self-discipline." Was this true of Catholic women? Were they encouraged to keep a diary? Were they supposed to submit it to their religious teachers? While Campbell is not concerned with the manifestations of patriarchy in a certain place and time and among different social classes, the reader can nonetheless infer much from the diaries about gender relations within the family and in social institutions such as the churches and schools. Campbell is not concerned with the manifestations of patriarchy in a certain place and time, among different social classes, but from the diaries she consulted the reader can infer much about gender relations within the family and in social institutions such as the churches and the schools.

\section{Quebec women writing themselves}

Patricia Smart's analysis of Quebec women's autobiographical writing over three centuries proceeds chronologically and by genres. Given the scope of her corpus, however, it is not possible to follow the same themes throughout, leading her to adopt different foci for different periods. Guided by a feminist perspective, for each writer she looks specifically for gender differences in both form and content (65). Smart herself acknowledges that the diaries are not representative of all French Canadian women (117). So few of these documents have survived, and all are, in her view, so subjective, that one has to be extremely careful in using them as "evidence." They reflect the mindset of their times, along with their social and cultural milieu, but they are also the individual writings of women who rebelled or conformed, who had their own neuroses, who may have considered themselves unique, and who often expected their works to be read. 
These women are certainly exceptional as most of them do not adhere to the roles that were assigned to them at the time: cloistered nuns became adventurous and fearless in New France, Catholic daughters became feminists and one, Nelly Arcan, was a part-time prostitute. From 17 th century nuns to present-day novelists, all of Smart's women write about their inner self. Marie de l'Incarnation digs deeper than most in her mystical experience: "There is a back and forth movement between the inner and the outer world, but it is absolutely clear that the author is primarily interested in recounting her spiritual experience and the outer events are of relevance only to provide a context to this path towards God" (40).

After the first chapter on the prominent women of New France, Smart introduces the correspondence of Élizabeth Bégon (1696-1755) and of Julie Bruneau Papineau (1795-1862), wife of Louis-Joseph Papineau, which raise issues associated with separation and time during an era where the post initially took months, then weeks, and finally days to reach its destination. Their letters were written solely for the recipient. Bégon asked her son-in-law to burn her letters, and Papineau probably never expected that hers would be read by anyone other than her husband.

By the mid-19th century, a new genre had emerged: the personal diary. It owed much to the Romantic Movement and its concern with the self, and the notebook has become the confidant of young women ever since.9 Smart focuses on the diaries of Henriette Dessaulles and Joséphine Marchand, then turns to examine the journals of married women. She begins with those of Angélique Hay-Des Rivières from the Eastern Townships and Marie-Louise Globensky (Lady Lacoste) from Montreal, followed in the 2oth century by writer Michelle Le Normand and Ghislaine Perrault Laurendeau, all of whom were expected to be "Queen of the Hearth" (165-88).

For most women, marriage spelled the end of diary writing. Smart interprets this "as if the diarist understands that she no longer has a right to a space for private writing" (145). One could also add that women of the bourgeoisie suddenly found themselves responsible for the running of a household, possibly including domestics, and of balancing the family budget, looking after the needs and illnesses of children, and being forever subjected to "the claims of self and others" (178). In pursuing her diary until her death, Michelle Le Normand was exceptional. One wonders how she found the time to write after the birth of her three children, including a disabled daughter,

9 Philippe Lejeune, Le moi des Demoiselles. Enquête sur le journal de jeune fille (Paris: Éditions du Seuil, 1993). 
while following a literary career and also correcting her depressive husband's manuscripts and looking after their publications. In most cases, the husband, at least at the beginning of married life, became the new confidant who could be jealous of the written word that he might not even be permitted to see.

Smart presents three broad periods of Quebec women's history. First there is New France, starting with the early women missionaries and ending with Élizabeth Bégon, who shows "that it was possible for a woman of her era to have agency and to express herself freely, without feeling imprisoned in the mother role as later women would often be" (87). The British Conquest marks the beginning of the second era - a long period ending in the mid-1960s and characterized by an omnipotent Roman Catholic Church, domineering and complaining mothers, and a general climate of oppression. The Quiet Revolution, the beginning of a "modern era," ushers in the last period and marks a break in attitudes and experiences, opening Quebec women to the world and making them agents of their destiny - although Nelly Arcan's suicide suggests this was a blessing with mixed results.

In the 19th century, the letters of Julie Papineau, an unhappy woman who lost four children and had to cope with the other five during the long absences of her husband Louis-Joseph Papineau, summed up the bitter lot of women during this period:

The complaints, the resentment, the anger, and the frustration expressed in her letters, especially in her later years, are part of a constellation of emotions and behaviours which - judging by the private diaries written by young girls and women in the century after her death in 1862, as well as in the autobiographies of women who grew up in the years preceding the Quiet Revolution - will be passed on, from generation to generation, by Québec mothers until the beginning of the modern era (111).

A woman who deviated from the usual social expectations was Angélique HayDes Rivières who, despite the discourse on women's roles as mothers, "seems not to be overwhelmed by the responsibilities of motherhood, as Julia Papineau was, not even to be particularly conscious of a 'maternal role' to which she must conform" (170).

Smart presents women as exclusively destined to be the "Queens of the Hearth" and under the control of both the Church and of their own mothers 
until the mid-196os. Indeed, Michelle Le Normand, Claire Martin, Denise Desautels, and others complain about this. Yet these women's autobiographical writings sometimes belie the power of the Catholic Church. Smart writes that "the hundreds of books read by Le Normand over the years, carefully listed in her journal, reveal the rigidity and self-censorship imposed on her literary tastes by Catholic orthodoxy" (186). This list nevertheless contains many of the very authors that the Church condemned, including Proust, Gide, and Montherlant. In reality, Catholic censorship often proved to be very inefficient in its efforts to control what people could read. In Denise Desautel's autobiographical novel, her French pen pal writes of travelling to Paris to see the film Hiroshima Mon Amour. Smart comments that this was "almost unimaginable for young Québécoises in 1958." Released in Paris in 1959, the film did play in Montreal the next year, albeit with 13 minutes of censored content. ${ }^{10}$

The 1960s ushered in the so-called Quiet Revolution, a period that Susan Mann Trofimenkoff once called "Noisy Evolution." 11 It was, in fact, a bit of both and a long time in incubation. In the last part of the book, devoted to “The Age of Autobiography, 1965-2012," Smart casts a wide net to include autobiographical novels, arguing that they all play a role in the construction of their author's self and contain "infratextual signs ... which anchor them clearly in the lived experience of the authors as it can be verified outside the text" (191). All the texts selected for this period have been published. Works by Denise Bombardier, France Théorêt, and Denise Daviau's are clearly labelled as a "novel" by their authors, but Smart considers them within the same category of documents as the autobiographies of Marcelle Brisson and Francine Noël (245-6).

Smart's interpretation of these women's lives and writings illustrates the tension between the author's interpretation of Quebec history and the testimonies of different women she calls upon to support this understanding. In fact the writings of the women studied by Smart tend to reveal how the Catholic Church's efforts to control people were glaringly inefficient, widening the gap between the prescriptive discourse and individual practices. Ultimately, Smart seems to be pulled in two directions. She accepts Lejeune's autobiographical pact (even in books identified as novels) to confirm her

10 In 1964, the film was shown in its integrality; see Pierre Hébert, Yves Lever et Kenneth Landry, Dictionnaire de la censure au Québec. Littérature et cinéma (Montréal: Fides, 2006), 311-14.

11 Susan Mann Trofimenkoff, Dream of Nation: A Social and Intellectual History of Quebec (Toronto: Forkner, 1982), 297. 
position on the dichotomy between pre- and post-Quiet Revolution Quebec, yet she qualifies her conclusions as follows:

Is it possible to generalise on the basis of a few examples about the situation of women in Québec - that of the so-called "queens of the hearth" who reigned over the pre-Quiet Revolution families, or that of their daughters in the 1960s, when changes in women's roles had begun to take place? (255)

Smart does an excellent job in identifying the double function of autobiographies. They are both historical documents and personal instruments of identity construction. Autobiographical writings, as historical sources, have to be handled carefully and critically, and Smart recognizes that; yet when Claire Martin writes "We had no right to knowledge, either generalised or specialised" (207), her statement needs further probing. While Claire Martin's autobiography deals with rural poverty, the chapter "Growing up Poor in Montreal" focuses on the urban poverty of women who nevertheless made remarkable achievements with careers in politics (Lise Payette), journalism (Denise Bombardier, Adèle Lauzon), and writing (France Théôrêt, Marcelle Brisson). If, as they were so constrained by the Catholic Church, their mothers, and their children until the end of the 1960s, how did they succeed so well in life? Smart introduces us to a coterie of women who nonetheless managed to shape their own lives and play an important role in Quebec society as philanthropists, feminists, librarians, journalists, and authors.

Since these two books use autobiographical writings to broaden our knowledge of the history of women, they invite comparison. Smart's corpus is much wider than Campbell's, and includes all forms of autobiographical writings - moving from journals and letters to autobiographies, memoirs, and even auto-fiction. The reader can, though, find some common ground in these two studies as during the 19th century women in Quebec and New Brunswick shared many common experiences. At some time or another, for instance, all families experienced the absence of husbands and fathers when men went lumbering or sailing, or sat in legislatures in Quebec or Ottawa, while their wives increasingly shouldered the responsibilities at home.

Both Campbell and Smart examine the private and public spheres. Campbell does so to show how they intersected but were seldom clearly demarcated. Smart stresses their differences and the predominance of the 
private sphere, especially after marriage, even though many of her subjects were interested in politics and community work and became writers, journalists, and public figures.

Religion permeated the lives of Christian Canadian and Quebec women during the 19th century, and Protestant denominations were no less constraining than the Catholic Church was albeit it in different ways. Smart portrays women as living during "two centuries of Church-dominated submission that followed the Conquest." Still, in most of the texts she examines, religion, faith, and church are no more present and constraining than in the anglophone Protestant diaries of Campbell's New Brunswick women who attended church functions almost every day (159). Nor were young women very different in their leisure activities, whether in austere Protestant communities or in devout Catholic families. Women of the bourgeoisie danced in each other's homes, they partied till dawn in Montreal or Cumberland County, they dreamed, they flirted, and they gossiped. Digging in other sources, such as official documents and statistical data, Campbell has endeavoured to flesh out women's lives and give us a history of their time. Smart, tackling a much longer period, has focused on the works themselves and the authors who were "writing themselves into being." Thus, two different approaches to using autobiographical materials help illustrate the breadth of purpose to which they can be used. Both Campbell and Smart, in these two very different works, enrich our understanding of women's history and illustrate the wealth of knowledge that can be extracted from autobiographical writings.

ANDRÉE LÉVESQUE

La professeure émérite ANDRÉE LÉVESQUE de l'Université McGill est une spécialiste de l'histoire des femmes. Elle est la directrice des Archives Passe-Mémoire, un centre d'archives qui recueille les écrits autobiographiques de "gens ordinaires ». On lui doit notamment l'ouvrage biographique Éva Circé-Côté : libre-penseuse, 1871-1949 (Montréal, Remue-ménage, 2010).

McGill University professor emerita ANDRÉE LÉVESQUE is a specialist in women's history. She is director of Archives Passe-Mémoire, an archive centre that collects autobiographical writings of "ordinary people" and one of her most recent books is Freethinker: The Life and Works of Éva CircéCôté (Toronto: Between the Lines, 2017). 